This file is to be used only for a purpose specified by Palgrave Macmillan, such as checking proofs, preparing an index, reviewing, endorsing or planning coursework/other institutional needs. You may store and print the file and share it with others helping you with the specified purpose, but under no circumstances may the file be distributed or otherwise made accessible to any other third parties without the express prior permission of Palgrave Macmillan.

Please contact rights@palgrave.com if you have any queries regeding use of the file.

\title{
License to Care? Migrant Domestic Workers in Spanish Employment and Family Policy
}

\author{
Elin Peterson
}

\section{Introduction}

Migrant women have come to play an important role as care and domestic workers in private households in Europe. The insertion of migrant women in domestic service often bridges the gap between the need for care and the lack of public or subsidized private services. The globalization of care is particularly significant in southern European contexts where public care provision is scarce and cheap migrant labor is being demanded by average- and highincome households aspiring to combine employment and family life. Activists and researchers have advocated for domestic workers' labor rights and the recognition of domestic and care work as real work. They have been more silent on the right to family life of domestic workers - the right to combine paid work and care for their families. Based on a case study of Spain, this chapter analyzes the framing of domestic work and workers in domestic employment and family policies. It aims to explore these questions: How do Spanish employment and family policies frame domestic workers? In what ways do these policies (re)produce inequalities related to gender, class and migrant background?

Domestic workers' labor rights recently appeared on the political agenda in Spain. The Special Regime for Domestic Workers, ${ }^{1}$ established in 1985, constructed domestic work as "different" from other kinds of work. The space in which it takes place, the home, legitimized weaker labor and social rights for domestic workers than those of other workers. A reform from 2011 addressed the legal status, reframing paid domestic work towards "real work" (León 2013). However, the strong presence of the informal economy cast doubts on the prospects of a substantive change. Family policy has been articulated as the promotion of the reconciliation of work and family life in Spain. Improving the possibilities to combine work and family life has been at the heart of Spanish gender equality-related policies (Peterson 2007, 2011). While working mothers have been 
the main subjects of these policies, domestic workers have been recognized as necessary for Spanish families to be able to reconcile paid work and care. But the needs of domestic workers have been largely invisible in this debate. In the current context of the economic crisis both work and care-related rights are being restricted, conditioning the work and family life of migrant domestic workers.

\section{Gender, care and social policy analysis}

Feminists have often considered care and domestic work as a common burden imposed on women (Anderson 2000). Feminist research on the welfare state has mainly focused on women's unpaid care and domestic work within the family unit. Social policy has then been seen as potentially liberating women from this work. As such, gender equality has been associated with equality for white, heterosexual, working mothers (Kantola 2006). But the idea that all women share the same work/care dilemmas must be questioned. As postcolonial researchers have pointed out, care and domestic work has historically encompassed categories of gender, class and race/ethnicity (Lewis 2006). Studies on the globalization of care work have raised questions about different forms of social inequality and divisions among women in the global economy of care. Researchers have, for instance, highlighted the exploitative conditions of domestic work, asymmetrical power relations between (female) workers and employers, and racist stereotypes that underpin the employment of certain ethnic groups and nationalities (Anderson and Phizacklea 1997; Caixeta et al. 2004). The globalization of care work reinforces the need for an "intersectional" approach to social policy and welfare states (Lutz 2002; Kvist and Peterson 2010). Hence, in my analysis, "women" is considered both a normative and exclusionary category, and "gender" is understood as interlocked with class, race/ethnicity and sexuality (Staunæs 2003; Brah and Phoenix 2004). Further, the analysis draws attention to normative assumptions regarding gender equality in employment and family policies.

The analysis presented here draws upon a case study of Spain that analyzes the official policy documents such as acts, parliamentary debates, government bills, policy plans, and policy reports from 1995 to 2011 (Peterson 2011). The documents selected represent Spanish employment and family policy. The policy analysis is inspired by the approach of Bacchi (1999), What's the problem represented to be? This approach rests on the presumption that there are no objective policy problems; or that problems are constructed within political discourse. Discourses can be seen as systems of thoughts composed of ideas, beliefs, and practices (Lessa 2006). As such, discourses make visible certain issues and marginalize others. In order to shed light on this process, the analytical focus falls upon normative assumptions embedded in public 


\section{PROOF}

License to Care? Migrant Domestic Workers 75

policies. Absences in the agenda are significant since they say something about what is being marginalized, or goes unquestioned. Discourses are important because of their effects on different groups; that is, some groups are privileged while others are marginalized. As an example, the analysis attempts to show how policies that aim to facilitate the reconciliation of work and family life, and also generally aim to improve gender equality, can also marginalize the "other" - migrant women and domestic workers. State policies condition (migrant) domestic workers' lives. Hence, the analysis of dominant policy frames reveals how the policies shape domestic workers' opportunities and constraints.

\section{Global care and national policy}

Globalization is often thought to be about international production and financial markets. However, it is also about the migration of workers like domestic workers. In this case, care work has indeed become part of the globalization process. While studies on the globalization of care work and "global care chains" (Hochschild 2001) often take a sociological bottom-up perspective, the role of the state remains less explored (Spanger, Peterson, and Dahl 2013). Importantly, all welfare states position themselves in relation to care: how it should be performed, by whom, and where (Sundström 2003). The way in which the European welfare states organize care is changing in the context of their restructuring, aging populations, and the current economic crisis. Given the divergence between the need for care and the lack of adequate care services in Europe, migrant women have been brought into care and domestic work (Kofman 2001; Lister et al. 2007; Williams and Gavanas 2008; Widding Isaksen 2010). The Southern European family care model (Anttonen and Sipilä 1996) involves limited public care provision, predominance of informal family care, and increasing market for domestic care services. While low-income households have to rely on informal unpaid care provided by family members, medium and high-income households use domestic services. Within this vein, the phenomenon of global care chains has been argued to be particularly significant in the southern European countries (Kofman 2001; Anttonen 2005; Parreñas 2005).

Spanish policies to facilitate the reconciliation of work and family life emerged at the end of the 1990s in the context of an increasing participation of women in the formal labor market. The Spanish welfare state has typically been characterized by the normative division between the male breadwinner and the female caretaker. Feminist researchers have widely criticized the ways in which the welfare state attributes a key role to the family and, hence, women's unpaid care and domestic work (Threlfall, Cousins, and Valiente 2005). Since Spain has moved towards a model where both women and men are expected to be 
waged workers, women's workload within the family is no longer sustainable (Anttonen 2005). Rather than public care provision and collective solutions to seek a balance between work and family life, private and individual solutions to care dilemmas remain central. Caring for the elderly in private homes has turned into a frequent occupation among migrant women in Spain (Escriva and Skinner 2008; Martínez Buján 2010 and 2011). Families with small children also employ migrant domestic workers as a strategy to combine work and care (Tobío 2005). Consequently, the supply of domestic workers has been promoted by the state through its immigration policies. The successive modifications of the Aliens Act have established a policy designed to meet demographic, labor and economic needs, and the incorporation of migrants in domestic work has been facilitated through a quota system (Anthias and Lazaridis 2000; Kofman 2001; Lutz 2002). In contrast, with the austerity policies adopted in the name of the economic crisis, migrants' rights to health care have been restricted. A legislative decree adopted by the Conservative government in 2012 made the health card contingent upon legal residence and affiliation to the social security program.

The domestic service sector is both highly feminized and "foreignized". Statistics from 2009 show that over 90 percent of the employees registered with the Special Regime for Domestic Workers were women and 63 percent of the registered employees were non-nationals (INE 2009). A study carried out by the Institute of Older People and Social Services estimates that in the case of "live-in" care workers 81.3 percent of the domestic workers were foreigners (IMERSO 2004, in Martínez 2007, 121). There has been a steady increase in the numbers of migrant domestic workers in formal domestic work (i.e., formal employment including social security) since the 1990s; the number of foreign domestic workers has risen from 15,500 in 1996 to 320,700 in 2009 (León 2010, 409-410). At the same time, domestic service work still belongs to the underground economy. All in all, domestic work employment is considerably higher in Spain than most other European countries. According to the 2009 Spanish Labor Force Survey, there were over half a million people working in the household sector (León 2013, 172).

As Lutz (2002) underlines, domestic work involves heterogeneous tasks ranging from cleaning, washing and cooking to caring for children, the elderly, and the infirm. In Spain, domestic service most often involves care work, given the lack of public care provision. The statistics based on the Social Security register do not distinguish between domestic tasks and care work; all go under the title "domestic service", rendering caregiving work invisible. As Martínez (2007) contends, in the Spanish context it is more adequate to speak of "domestic care work" - recognizing the care work performed by domestic workers. 


\section{PROOF}

License to Care? Migrant Domestic Workers 77

\section{Domestic workers and workers' rights}

The Special Regime for Domestic Workers, established in Act 1424/1985, provides an important background for domestic workers' rights in Spain. This Social Security regime regulated employment in domestic service for over two decades, providing far less social protection than the General Regime of the Social Security system (León 2010, 2013). When it comes to the Social Security contributions that employers and employees were required to pay, the Special Regime required lower contributions. The protection offered was consequently weaker: the Special Regime for Domestic Workers did not include unemployment benefits; work-related illnesses and accidents were not recognized, sickness was not covered until day 29 and the retirement pension was extremely poor. The employer was required to pay Social Security contributions only if the number of working hours exceeded 20 per week. There was no obligation to draft and sign a written employment contract, but only to come to a mutual verbal agreement. Moreover, up to 45 percent of the salary could be paid in kind and unpaid "presence" time was acknowledged as part of the job. Although the Special Regime was already created in the late 1960s to protect those working in private homes with no formal recognition, domestic work was not recognized in the labor law until the 1985 Act. However, the 1985 regulation defined private homes as "exceptional contexts" and by appealing to the priority of rights of privacy and private family life over labor rights, workers' rights were subordinated to employers' rights (León 2010, 414-415). Additionally, the recognition of this exceptional character by the 1985 regulation meant that domestic employment would not be included within the Workers' Bill of Rights.

Not surprisingly, the Special Regime was widely criticized. In fact, the European Commission criticized the Special Regime for Domestic Workers on the basis that it violated the European Directive on equal treatment of men and women, and particularly the Directive 79/7/EEC on equal treatment in the Social Security system. The main trade unions, the General Workers' Union UGT and the Workers' Commissions CCOO, have generally promoted the incorporation of the Special Regime into the General Regime. But the trade unions have also been criticized for being passive and ignoring the specific problems of domestic workers. Other organizations, such as domestic workers' organizations, NGOs, and religious organizations have advocated the rights of domestic workers, including migrant workers. The advocacy for a change in the Special Regime for Domestic Workers has also existed within the women's movement for a long time, but paid domestic work has been less prominent than women's unpaid work in the home or "family care". In any case, there has been joint mobilization surrounding the issue of domestic service by the feminist movement and domestic workers' organizations. For instance, in March 2010 a 
demonstration in Madrid demanded "the end of slavery" for domestic workers (Peterson 2011).

In spite of advocacy for domestic workers' rights, there has been very little official policy debate surrounding domestic service and the Special Regime. In the Spanish parliament, domestic workers' rights were set in the center of the debate on only one occasion in the last two decades, in June 2005. This parliamentary debate is interesting as it revealed shared understandings of the role that paid domestic work played in Spanish society. Overall, the "different" nature of domestic work was underlined. On the one hand, the servitude historically inherent in this work was emphasized and, on the other hand, the idea of essentially different work legitimated different (e.g., weaker) social rights:

One of the paradigmatic elements defining the rights of the worker is that the connection between a worker and an employer is characterized by the definition of dependence. In the field of work of the female and male workers who provide domestic service, the dependence entails conceptual dimensions that are particularly different from what the jurisprudence of the Constitutional Court has established in this area. The dependence is not only performing work for a salary; we are here talking about a concept of dependence that resembles [...] the times of the heritage of the first-born son, the dependence of the Lords and the Masters. (MP Emilio Olabarría Muñoz, Basque Nationalist Party PNV, Parliamentary Debate 21 June 2005, Records of Proceedings in the Congress, 4924)

On the one hand, the employer is not really an employer but rather a head of family who does not profit in a stringent sense from the work but this assistance covers an apparent need in our society, and the employed person is often used as a substitute when work is not compatible with family life $[\ldots]$ we have an employee that offers assistance in a very specific context, at times within a frame of confidence/distrust and familiarity, where not all time of presence is real work, where the framework of rights is relative, and where life and work are intimately connected to the point that one can often not distinguish between them. (MP Joan Tardá I Coma, Catalonian left-wing party Esquerra Republicana, Parliamentary Debate 21 June 2005, Records of Proceedings in the Congress, 4925)

Scholars have engaged in disputes about whether domestic work is different in nature or can be just another job. I argue that the crucial question is not whether this work is a priori different or not, but how this work has been constructed in specific contexts. In the Spanish context, the framing of paid domestic work as "different" is problematic as this difference justifies weaker 


\section{PROOF}

License to Care? Migrant Domestic Workers 79

rights. This framing of paid domestic work is rooted in the history of servitude, which reproduces social inequalities.

In the parliamentary debate, the problem of inequalities and precarious work was recognized. Paid domestic work was related to undervalued, feminized work and female migrants' precarious working conditions. Improving the conditions of paid domestic work was about justice for the many women working in the sector and equality between domestic workers and other workers. One Member of Parliament (MP) highlighted that domestic work of native women is more and more often being replaced by remunerated tasks performed by a [female] worker, often immigrant, who for a rather low salary is willing to perform the little recognized domestic tasks that "we natives are not prepared to assume." It was pointed out that the augmentation of the number of migrant women in the sector of domestic work reinforces social and economic inequalities and integration problems. It was argued that domestic work has "changed in nature" increasingly involving care, and that this changing character of the work should result in a higher valuation. However, studies have shown that domestic care work is most often labeled "unskilled" and, thus, its little social value is legitimized (Lister et al. 2007).

The focus on domestic workers' rights contrasted with a discourse that stressed economic growth and stability, and employment. The MPs stressed middleclass families' interests and "quality of life." Domestic workers were debated in terms of providing solutions in the context of the care deficit, to help Spanish families and to facilitate the "reconciliation of work and family life". How to satisfy the demands of middle-class families where both men and women work was framed as a central issue. There was a general agreement that families need domestic workers; both left- and right-wing parties emphasized that the problem was not only about the lack of labor rights of domestic workers, but also about families' access to domestic workers. While improving the rights of domestic workers should not put state finances in danger, domestic workers were seen as essential to solving the care deficit and to improving the reconciliation of work and family life, too, and even more so in the future.

We should be aware that domestic work or employment will become more demanded in Spain due to the increasing incorporation of women in the labor market, as occurs in our neighboring countries. It is work that every day becomes more necessary in order to better reconcile work and family life. (MP Lourdes Méndez Monasterio, Conservative Party, Parliamentary Debate 21 June 2005, Records of Proceedings in the Congress, 4927)

It was argued that any reform of the Special Regime for Domestic Workers should, by no means, imply making the services more expensive for "middle-class 
families". The lack of welfare state provision for dependent care was used as a justification as to why families need domestic workers.

The labor reform of domestic service and its special characteristics, hence, is a necessity that should be considered since it is about a work sector that is very much linked to support to families with dependent persons in a context where these families enjoy scarce support. In short, the reform should improve the rights to equality of the workers and the rights of families to access a support in domestic work that does not penalize their possibilities of development and particularly their possibilities of reconciling work and family life. (MP Ángel Pérez Martínez, Left Party, Parliamentary Debate, 21 June 2005, Records of Proceedings in the Congress, 4923)

In the context of scarce public care provision, domestic workers are seen as necessary for Spanish families. Yet, the acceptance of individual solutions for care seems to reinforce the legitimacy of the "non-caring state" (Daly 2001). Emphasizing Spanish families' access to (migrant) domestic workers can be seen as legitimizing limited state responsibility and scarce welfare state provision.

The employment of domestic workers for eldercare is a common practice and has been indirectly fomented through the introduction of the family allowance in the Dependent Care Act adopted in 2006. The Dependent Care Act put eldercare on the agenda. A new citizen right was adopted in order to guarantee minimum national standards for those receiving care. This reform involved a shift away from the dominant view of eldercare as almost exclusively a private matter, constructing it as a public concern. The reform was labeled a gender equality project: the welfare state would help liberate women from their care responsibilities to paid work. Nevertheless, the taken-for-granted construction of care as women's work was left unchallenged. The allowance for the so-called non-professional family care was by no means constituted as a worker's salary but a support. Remarkably, the Dependent Care Act completely ignored the category of domestic care workers and the role they play in eldercare in Spain. As such, the rights and working conditions of this category of care workers were marginalized as a political issue.

In contrast, coinciding with the 2011 International Labor Organization (ILO) landmark treaty on decent work for domestic workers, a reform addressed the legal status of household employees, reframing paid domestic work towards "real work" (León 2013). The Socialist PSOE government in power at the time, the employers' organizations, and the two main trade unions signed an agreement to put domestic workers on an equal footing with other workers. That same year, Act 1620/2011 was passed which regulates the "special labor relation of household service". By merging the Special Regime for Domestic Workers with the General Regime, rights and working conditions were improved for 


\section{PROOF}

License to Care? Migrant Domestic Workers 81

domestic workers in formal employment. Among other things, the Act established that tasks and working hours have to be agreed on by both parties and specified in an employment contract. The salary cannot go below minimum wage and "presence" time has to count as paid working hours. Sickness benefits are conceded after the fourth day of illness. For live-ins, 30 percent of the salary can be paid in kind but this reduction is subjected to conditions stipulated in the Workers' Bill of Rights.

Although the reform meant advancing towards equal rights, the work is still defined as "special" which legitimizes, for instance, the exclusion of domestic workers from unemployment benefits. Central to the understanding of domestic work as a special labor relation is that this work takes place in the private sphere, in the home, and is reproductive work, contrasted with productive work in the public sphere. However, the new regulation does not recognize the caregiving work domestic workers perform for dependent people. As such, care for the elderly in private homes becomes just another domestic task. Notably, the Act does not acknowledge the struggles of domestic workers' and feminist organizations claiming visibility of care work and advocating justice for domestic workers.

\section{Domestic workers and family rights}

After the end of the Franco regime in 1975 there was a resistance among both left- and right-wing parties to speak about the need for family policies (Carlos 2000; Tobío 2005; León 2007). Family policy was associated with the Fascist regime's pro-natal and anti-feminist ideology (Naldini 2000). It was not until the late 1990s that family issues explicitly entered the political agenda again. This shift was related to the promotion of policies to facilitate the combining of work and family life by the European Union.

The Conservative government of Partido Popular 1996-2004 made the reconciliation of work and family life a key issue (Salido 2009, 283). The policies that aimed to address the reconciliation of work and family life framed the issue in terms of working mothers' problems of managing paid and unpaid work. Act 39/1999 to Promote Workers' Reconciliation of Family and Work Life emphasized the link between the reconciliation problem and working mothers by focusing on rights related to maternity leave. Fathers were attributed the role of substitutes in the care for small children and continued without an individual right to paternity leave. During their government the Conservative party emphasized that mothers should be able to develop their professional careers and have as many children as they want. To make family and work responsibilities compatible was considered an important national goal.

The working mother was put forward as the subject of these policies. Central to the debates was women's labor market participation - seen as a requisite 
for women's equality and considered good for society because of their contribution to the economy. The lack of sharing of unpaid care and domestic work between women and men was a marginal problem; only a few policy measures addressed men. Furthermore, the accent on family responsibility (re)produced the sexual division of work. Intergenerational solidarity was emphasized; the family was considered the guarantee of social cohesion and responsible for the future well-being of the nation:

The social changes of the incorporation of women into the labor market, the declining birth-rates and the ageing of our population are a reality, and the success of the future of this new society depends on that families freely can carry out the role that corresponds to them. (Integral Plan of Family Support 2001-4, Ministry of Labor and Social Affairs 2001, 108)

Women were generally represented as a homogeneous group, supposedly sharing the same problems of combining care and work responsibilities, and yet, the "working mother" operated as an exclusionary norm. The tax reform from 2002 is a clear example; it gave working mothers the right to a subsidy of $€ 100$ per month for each child under three years of age, "with the aim of compensating for social and labor related costs derived from maternity" (Act 46/2002). This reform (re)produced the normative assumption of women, and not men, as caregivers albeit addressing only mothers with formal employment, thus excluding various groups of women from benefits; unemployed women and women working in the underground economy - often participated by migrant and working-class women.

The Socialist government in power from 2004 to 2011 emphasized the problem of gender inequality and women's unpaid care and domestic work. During the era of the Socialist government the focus was extended from working mothers to fathers and the norm of "co-responsibility" between women and men in care and domestic work was introduced. The Act for De Facto Equality between Women and Men introduced an individual right to paternity leave, which was represented as the most innovative measure to promote "greater co-responsibility between women and men in assuming family obligations" (Act 3/2007). Although recognizing the role of fathers in care work, the right to two weeks of paternity leave can be seen as a symbolic rather than a substantial change. Moreover, gender equality continued to be located within a discourse of stressing the economy and employment, promoting "women's employability". Hence, women's adaptation to labor market requirements was a priority, not the adaptation of the working world to women's needs. During both the Conservative (1996-2004) and the Socialist governments (2004-2011) the (re)production of the sexual division of labor, along divisions of class, race/ ethnicity and nationality, by transferring care and domestic work to "other" 


\section{PROOF}

License to Care? Migrant Domestic Workers 83

women, for example, domestic workers, was not a matter for discussion. Gender equality was linked to women's unpaid care and domestic work. Little attention has been paid to the issue of paid domestic care work.

In immigration policy "immigrant women" emerged as a category with more problems of reconciling work and care than Spanish women. While the policy debate on reconciliation produced a homogeneous category of women, implicitly referring to white Spanish women, the Strategic Plan for Citizenship and Integration (2007-2010), elaborated by the Ministry of Labor and Social Affairs (2007) focused on the problem of unequal distribution of care and domestic work in immigrant families. Immigrant women's exclusive responsibility in domestic work and care for children and other dependents was conceived as a problem because it restrained their possibilities of integration in Spanish society:

If one studies the roles and activities in the private sphere, one will observe situations of inequality in the distribution of responsibilities and tasks in the family, which can turn into determinant factors of exclusion in the processes of social integration of immigrant women [...] they continue to alone carry out the care work that corresponds to the reproductive sphere in their own homes. (Strategic Plan for Citizenship and Integration 2007-2010, Ministry of Labor and Social Affairs 2007, 305-6)

While the plan constructed the reconciliation as a problem of integration, it produced a homogeneous category of "immigrant women". The plan stated that immigrant women alone do all the care and domestic work by themselves, implicitly considering their partners (immigrant men?) as responsible for their lack of integration. Other aspects, hardly ever raised in relation to "modern" Spanish women, were added to the problem: the inequality in decision-making and income distribution. The problem of unequal distribution of care and domestic work was thus represented in a way that went beyond dominant representations of reconciliation and the lack of co-responsibility in the general policy debate, producing an image of immigrant families as a site of greater gender inequalities than Spanish families. These representations were founded on general assumptions of immigrant women's problems and produced an image of the "Third-World woman" as the oppressed "other" (Mohanty 1994). In contrast, the way gender inequality interacts with, for instance, racism and class inequalities was downplayed. Differences among "immigrant women" were ignored. There was a remarkable silence on the role of migrant women in facilitating the reconciliation of work and family life of Spanish men and women. In the context of the global care chains, many migrant women are not able to bring their families with them as they migrate and they have to care for their own children or elderly parents from a distance. 
In spite of the general invisibility of migrants and domestic workers in family policy, however, some important policy changes should be highlighted. While the Reconciliation Act from 1999 excluded workers registered with the Special Regime for Domestic Workers from the right to maternity leave, the 2007 Equality Act extended the right to maternity leave to include domestic workers. What is more, the regulation of Household Employment in force since 2012 affirms that domestic workers have the same rights as other workers in terms of reconciling work and family life, parental leave, and other unpaid leave. Nevertheless, while the reform implies a step forward in recognizing the family rights of domestic workers, it is uncertain what role it will play in current times of economic crisis and extremely high unemployment. The lack of political will to control the compliance of the law and the strong presence of the informal economy (León 2013) cast doubts on the prospects of meaningful change.

\section{How do public policies shape inequalities?}

Spanish employment policies have shaped social inequalities by constructing paid domestic work as essentially different from other kinds of work. This idea has underpinned the particular legal status of domestic workers in Spain. The framing of domestic work as different legitimized for a long time weaker social protection and labor rights. As such, the conditions in this sector have often been characterized by servitude. After many years of criticism of the Special Regime for Domestic Workers, domestic workers' rights appeared on the political agenda. The new regulation on Household Employment reframes domestic service as a question of workers' rights. Nonetheless, the fact that the work is performed in the home still justifies some distinctive labor rights. In spite of the importance of domestic workers in care provision for older people, there is still no recognition of this caregiving work in public policy.

Family policy has been articulated as the promotion of the "reconciliation of work and family life", considered the heart of gender equality policy in Spain. "Working mothers" have been the main subjects of these policies. Further, policies have privileged some women's care dilemmas over others. Migrant workers have been invisible as care dilemmas are associated with white, autochthonous, middle-class women's problems of combining paid work and unpaid care. Obviously, many migrant women are "working mothers", too, but dominant discourses on the reconciliation of work and family life have marginalized migrant women and their interests. Moreover, at the policy level, the sexual division of labor is rendered unproblematic when domestic work is externalized to working-class and migrant women. Policy debates have made it clear that middle-class families' access to domestic workers is a priority. Resorting to the cheap labor of migrant domestic workers has become a valid solution to 


\section{PROOF}

License to Care? Migrant Domestic Workers 85

the care deficit. And, generally, there has been little official discussion on the conditions of this work.

Nevertheless, steps have recently been taken to improve domestic workers' rights as workers - with the right to family life. With the Equality Act of 2007 and the Household Employment Act of 2011, formally employed domestic workers have the same rights as other workers to paid and unpaid leave to reconcile work and family. The question remains, however, whether the rights will be effective and working conditions will improve, considering the unfavorable economic and political situation. After eight years in opposition, the Conservative Party, Partido Popular, is back in power amidst the economic and financial crises facing the country. The crisis influences Spanish politics and society as a whole, resulting in a backlash of social policies. Families will most likely have to depend even more on individual strategies. For migrant domestic workers, the working conditions are influenced by the general context of the crisis and high unemployment. Turning domestic and care work into decent work is still a pending matter.

\section{Note}

1. Real Decreto 1424/1985, de 1 de agosto, por el que se regula la relación laboral de carácter especial del Servicio del Hogar Familiar.

\section{References}

Anderson, B. 2000. Doing the Dirty Work? The Global Politics of Domestic Labour. London: Zed Books.

Anderson, B. and Phizacklea, A. 1997. Migrant Domestic Workers: A European Perspective. Report for the Equal Opportunities Unit, DGV. Brussels: Commission of the European Communities.

Anthias, F. and Lazaridis, G. 2000. Gender and Migration in Southern Europe: Women on the Move. Oxford: Berg.

Anttonen, A. 2005. "Hacia un mayor cuidado público: cambios en las relaciones y las políticas públicas de cuidado a las personas dependientes", Panorama Social (FUNCAS, Madrid), 2: 8-20.

Anttonen, A. and Sipilä, J. 1996. "European Social Care Services: Is It Possible to Identify Models?", Journal of European Social Policy, 6 (2): 87-100.

Bacchi, C. 1999. Women, Policy and Politics. The Construction of Policy Problems. London: SAGE.

Brah, A. and Phoenix, A. 2004. "Ain't I a Woman? Revisiting Intersectionality", Journal of International Women's Studies, 5 (3): 75-86.

Caixeta, L., Gutierrez, E., Silvina, M., Tate, S., and Vega, C. 2004. Homes, Caretaking, Frontiers. Madrid: Traficantes de Sueños.

Carlos, M. P. 2000. "The Politics of Family Policies: Greece, Spain, and Portugal Compared", in A. Pfenning and T. Bahle (eds), Families and Family Policies in Europe: Comparative Perspectives, 49-69. Oxford: Peter Lang. 
Daly, M. 2001. Care Work: The Quest for Security. Geneva: International Labour Organization.

Escriva, A. and Skinner, E. 2008. "Domestic Work and Transnational Care Chains in Spain", in H. Lutz (ed.), Migration and Domestic Work, 113-126. Aldershot: Ashgate.

Hochschild, A. 2001 "Global Care Chains and Emotional Surplus Value", in W. Hutton and A. Giddens (eds), On the Edge: Living with Global Capitalism, 130-146. London: Vintage.

INE Spanish National Statistics Institute. 2009. Labour Force Survey.

Kantola, J. 2006. Feminists Theorize the State. New York: Palgrave Macmillan.

Kofman, E. 2001. Gender and International Migration in Europe: Employment, Welfare and Politics. London: Routledge.

Kvist, E. and E. Peterson. 2010. "What Has Gender Equality Got to Do with It? An Analysis of Policy Debates on Domestic Services in the Welfare States of Spain and Sweden", NORA - Nordic Journal of Feminist and Gender Research, 18 (3): 185-203.

León, M. 2007. "Speeding up or Holding back? Institutional Factors in the Development of Childcare Provision in Spain", European Societies, 9 (3): 315-337.

León, M. 2010. "Migration and Care Work in Spain: The Domestic Sector Revisited", Social Policy \& Society, 9 (3): 409-418.

León, M. 2013. "A Real Job? Regulating Household Work: The Case of Spain", European Journal of Women's Studies, 20 (2): 170-188.

Lessa, I. 2006. "Discursive Struggles Within Social Welfare: Restaging Teen Motherhood", British Journal of Social Work, 36 (2): 283-298.

Lewis, G. 2006. "Imaginaries of Europe, Technologies of Gender, Economies of Power", European Journal of Women's Studies, 13 (2): 87-102.

Lister, R., Williams, F., Anttonen, A., Bussemaker, J., Gerhard, U., Heinen, J., Johansson, S., Leira, A., Tobío, C., and Gavanas, A. 2007. Gendering Citizenship in Western Europe: New Challenges for Citizenship Research in a Cross-National Context. Bristol: Policy Press.

Lutz, H. 2002. "At Your Service Madam! The Globalization of Domestic Service", Feminist Review, 70: 89-104.

Martínez Buján, R. 2007. Bienestar y cuidados, el oficio del cariño. Mujeres inmigrantes y mayores nativos. Doctoral thesis, Faculty of Sociology, University of A Coruña.

Martínez Buján, R. 2010. "Servicio doméstico y trabajo de cuidados. Hacia la privatización del cuidado familiar." Alternativas: Cuadernos de Trabajo Social, 17: 157-179.

Martínez Buján, R. 2011. "La reorganización de los cuidados familiares en un contexto de migración internacional", Cuadernos de relaciones laborales, 29 (1): 93-123.

Ministry of Labor and Social Affairs. 2001. Integral Plan of Family Support 2001-2004.

Mohanty, C. T. 1994. "Under Western Eyes: Feminist Scholarship and Colonial Discourses", in P. Williams and L. Chrisman (eds), Colonial Discourse and Post-Colonial Theory: A Reader, 196-220. New York: Columbia University Press.

Naldini, M. 2000. "Family Allowances in Italy and Spain: Long Ways to Reform", in A. Pfenning and T. Bahle (eds), Families and Family Policies in Europe. Comparative Perspectives, 70-89. Oxford: Peter Lang.

Parreñas, R. S. 2005. "Gender Inequalities in the New Global Economy", in A. FauveChamoux (ed.), Domestic Service and the Formation of European Identity: Understanding the Globalization of Domestic Work, 16th-21st Centuries, 369-378. Oxford: Peter Lang Publishing Group.

Peterson, E. 2007. "The Invisible Carers: Framing Domestic Work(ers) in Gender Equality Policies in Spain", European Journal of Women's Studies, 14 (3): 265-280. 


\section{PROOF}

License to Care? Migrant Domestic Workers 87

Peterson, E. 2011. Beyond the "Women-Friendly" Welfare State: Framing Gender Inequality as a Policy Problem in Spanish and Swedish Politics of Care. Doctoral dissertation. University Complutense of Madrid.

Salido, O. 2009. "Familia y género", in L. Moreno (ed.), Reformas de las políticas del bienestar en España, 281-308. Madrid: Siglo XXI.

Spanger, M., Peterson, E., and Dahl, H. M. 2013. "How is the State Conditioning Global Care Chains? Framing, Tensions and Multi-Level Governance", Paper presented at the 7th ECPR General Conference, Bourdeaux, September 4-7.

Staunæs, D. 2003. "Where Have All the Subjects Gone? Bringing Together the Concepts of Intersectionality and Subjectification", NORA - Nordic Journal of Feminist and Gender Research, 11 (2): 101-110.

Sundström, E. 2003. Gender Regimes, Family Policies and Attitudes to Female Employment: A Comparison of Germany, Italy and Sweden. Doctoral thesis at the Department of Sociology, Umeå University.

Threlfall, M., Cousins, C., and Valiente, C. 2005. Gendering Spanish Democracy. New York: Routledge.

Tobío, C. 2005. Madres que trabajan. Dilemas y estrategias. Madrid: Cátedra.

Widding Isaksen, L. 2010. Global Care Work. Gender and Migration in Nordic Societies. Lund: Nordic Academic Press.

Williams, F. and Gavanas A. 2008. "The Intersection of Child-Care Regimes and Migration Regimes: A Three Country Study", in H. Lutz (ed.), Migration and Domestic Work, 13-28. Aldershot: Ashgate. 